\title{
PRODUCTION OF KERATINASES FROM NOCARDIOPSIS SP.28ROR AS A NOVEL IRAQI STRAIN
}

\author{
RABAB OMRAN*
}

Department of Biotechnology/Genetic Engineering, Biology, College of Science, University of Babylon, Babel, Al-Hillah, Iraq. Email: omranaljelawi@gmail.com

Received: 01 December 2016, Revised and Accepted: 03 January 2017

\section{ABSTRACT}

Objectives: Isolation a novel feather-degrading actinobacterial species had the ability to produce keratinases and antibacterial substances.

Methods: Of 23 actinobacterial isolates were recovered from farm soil, poultry farm soil and feather wastes, these isolates were screened for the protease, keratinase, and antibiotics production on skim milk agar, feather media, and Mauler-Hinton agar respectively. One potential isolate was identified depending on phenotypical, physiological and molecular characteristics according to the partial sequences of $16 \mathrm{~S}$ rRNA gene analysis and optimized keratinase production.

Results: 11 isolates out of 22 protease producer had the ability to degrade raw chicken feather and some of these isolates produced antibacterial metabolites against Staphylococcus aureus and Pseudomonas aeruginosa, 22.7\% and 10\%, respectively. The potential strain, Nocardiopsis sp. 28ROR (GenBank: KC702802.1), produced two types of extracellular keratinases in feather meal medium at $\mathrm{pH} 6$ (acid type), $30-35^{\circ} \mathrm{C}$ for 7 days and the alkaline keratinase at $\mathrm{pH} 10,40^{\circ} \mathrm{C}$ for 7 days, in addition to produce antibacterial against $S$. aureus.

Conclusion: The Nocardiopsis sp. 28ROR was a novel strain produced keratinases using feather meal degradation as a cheap waste medium. The wide tolerance of temperature and pH by keratinase makes it an ideal contender to be investigated further for potential application as a detergent additive and produce antimicrobial substances using feather meal medium.

Keywords: Nocardiopsis, Keratinase, Optimization, Feather medium, Antibiotic.

(C) 2017 The Authors. Published by Innovare Academic Sciences Pvt Ltd. This is an open access article under the CC BY license (http://creativecommons. org/licenses/by/4. 0/) DOI: http://dx.doi.org/10.22159/ajpcr.2017.v10i4.16427

\section{INTRODUCTION}

Keratin is the major component of bird feathers which found as $\beta$-keratin (beta sheets) and is a harder than $\alpha$-keratins (alpha helix) that the main protein components of animal hair, wool, nails, horn, and hoofs. Because of the complex protein structure of keratin polymers which are contained high percentages of disulfide bridges that converted a novel features such as complexity, rigidity and fibrous structure, insoluble nature, poorly degradable under anaerobic conditions, unreactive against most chemicals and it is not digested by pepsin, trypsin, or papain. Therefore, the accumulation of the keratin wastes in large quantities worldwide results in environmental pollution and protein wastage [1-3]. However, the keratin wastes, especially poultry feather waste are valuable sources for variety of amino acids, predominantly cystine, lysine, proline, and serine [3], and hence, a large amount is chemically and physically prepared to be used as feather meal and digestible nutritional for poultry and livestock. Because of the risk of disease transmission through a feed and food chain legislation on the recovery of organic materials for animal feed is becoming tighter $[3,4]$. Also, the source of keratin could be utilized to produce biodegradable polymers, fertilizer glues and films, or many selected amino acids as protein supplements, or to prepare media for culturing microbes for enzyme productions such as keratinolytic proteases, pharmaceutical and biomedical industries, leather manufacture, textile processing, detergent formulation, and waste management $[4,5]$. In addition to classical applications, the poultry feather waste is used to produce clothing, insulation, and bedding [5]

There are different species of microorganisms have the ability to degrade keratin materials by producing variant keratinase enzymes primarily including Bacillus such as Bacillus sp. JB 99, Bacillus subtilis, Bacillus licheniformis and other Bacillus species [5-10]; although, other Gram-positive bacteria, including Burkholderia, Chryseobacterium, Microbacterium sp., Streptomyces sp., Lysobacter, Nesterenkonia, Kocuria and Microbacterium, Gram-negative, Vibrio, Pseudomonas, Xanthomonas, Stenotrophomonas, Fervidobacterium, Thermoanaerobacter, and Nesterenkonia can also degrade keratin [4,5,10,11]. Riffel and Brandelli [12] isolated four bacterial strains from the feather on milk-agar plates and three were identified as Gram-negative bacteria (Burkholderia, Chryseobacterium, and Pseudomonas species) and one was identified as Gram-positive strain (Microbacterium species). Moreover, the soil samples are the main source of bacterial strains having potential degradation of keratin [13]. Korniłłowicz-Kowalska and Bohacz [14] investigated that actinomycetes belong to Streptomyces group, namely, Streptomyces fradiae, Streptomyces sp. A11, Streptomyces pactum, Streptomyces albidoflavus, Streptomyces thermoviolaceus SD8, and Streptomyces graminofaciens, in addition to Thermoactinomyces candidus, had the ability to produce keratinase enzymes and some of them produced antibiotics.

The genus Nocardiopsis secretes a range of novel extracellular enzymes that have been reviewed by Bennur et al. [15] such as alkaline tolerant enzymes, amylases, alkaline serine proteases, keratinolytic proteases and milk-clotting protease, as well as it produced antibacterial and antifungal substances.

The genus Nocardiopsis is a member of Nocardiopsaceae family and it was first described by Meyer in 1976. Depending on the basis of the phylogenetic position, morphological features and chemotaxonomic properties exhibited by Nocardiopsis species, it represented a distinct lineage within the radiation of the order "actinomycetales" [16]. This genus includes aerobic, Gram-positive, non-acid-fast, and catalasepositive actinomycetes. Colonies on organic media agar plates are coarsely wrinkled or folded. Their colonies are similar to members of the genera Nocardia and Actinomadura [17]. The substrate and aerial mycelia are well-developed and the latter fragments into spores. Nocardiopsis species like most of the other actinomycetes are 
generally associated with soils. Different types of soil samples (saline, hypersaline, desert, and alkaline) have yielded several novel isolates, mainly from China, Iran, and Egypt are other regions from where such isolates have been obtained. The most obvious trait of these isolates is their requirement for $\mathrm{NaCl}$ or tolerance toward it [18-23]. Most of the species have an optimum temperature between $28^{\circ} \mathrm{C}$ and $30^{\circ} \mathrm{C}$. One isolate obtained from compost (Nocardiopsis yanglingensis) was able to grow at $45^{\circ} \mathrm{C}$ and another one from Antarctica (Nocardiopsis fildesensis) was psychrotolerant and grew at $10^{\circ} \mathrm{C}$. A few isolates have also been obtained from Algeria, Germany, Seychelles, and Antarctica. The range of alkali tolerance, thermostable, and cold-adapted enzymes produced by some members of this genus [23].

Obviously, large amounts of keratinase for industrial scale processes are absolutely needed which is not cheap. Many studies have documented that bacteria capable of producing proteases having keratinolytic activity. However, best host cell for the overproduction of keratinase will still remain unknown. Several determinations have been performed to overproduce keratinase as demands expanding. It is now certain that many different species such as bacteria, actinomycetes, and fungi are able to produce keratinase. However, the level of production and providing conditions are still unclear and are yet to be discovered. The main objectives of this study were tried to isolate a novel feather-degrading actinobacterial species had the ability to produce keratinase enzymes and antimicrobial substances to formulate new medium for antibiotics composed from feather waste in the next research.

\section{METHODS}

\section{Feather meal preparation}

Feather meal was prepared from native chicken feathers as described by Saibabu et al. [24] with slight modifications. White feather waste was collected from local poultry slaughterhouses, and it was washed several times with soap and water to eliminate blood and dirt remainder, and then dried for $24 \mathrm{~h}$ in sunlight. The feathers were cut with scissors into small pieces of 1-3 cm long. Defatting of feather pieces was performed by soaking them in a mixture of chloroform:methanol (1:1) for $2 \mathrm{~d}$; followed by chloroform:acetone:methanol (4:1:3) for $2 \mathrm{~d}$. The solvent was replaced every day. The feathers were finally washed several times with tap water to eliminate the solvent residual, dried using oven at $40^{\circ} \mathrm{C}$ for $24 \mathrm{hrs}$, ground using an electric blender and used as feather meal.

\section{Bacterial isolation}

Fifty-five samples were collected from different sources such as farm soils, soils of a poultry farm and waste chicken feathers, and then transferred into plastic bags in the ice container. In Biotechnology and Genetic Engineering Laboratory at Babylon University in Babylon Province, the soil samples were ground, $1 \mathrm{~g}$ of powdered from each one was suspended in $100 \mathrm{ml}$ of physiological solution, mixed well and $1 \mathrm{ml}$ of the supernatant was cultured on sterilized media. The waste chicken feather samples were cut with scissors into small pieces of 1-2 cm long, $1 \mathrm{~g}$ of each one were soaked in $100 \mathrm{ml}$ of physiological solution, mixed well and $1 \mathrm{ml}$ of the supernatant was cultured on sterilized media. Three different media were used for bacterial isolation such as nutrient agar (Himedia), trypticase soy agar (Himedia), and yeast extract-malt extract Agar (International Streptomyces Project 2 [ISP2]) [25], which supplemented with $1 \%$ feather meal $(\mathrm{w} / \mathrm{v}), 100 \mu \mathrm{g} / \mathrm{ml}$ as a final concentration of nystatin as the antifungal agent and $10 \%$ of the soil extract at $\mathrm{pH}$ 9-10. The soil extract and antifungal substance were added to the media at $50^{\circ} \mathrm{C}$ after sterilization by autoclave at $121^{\circ} \mathrm{C}(15 \mathrm{lbs}$ pressure) for $20 \mathrm{~min}$. The soil extract was prepared by suspending $500 \mathrm{~g}$ of farm soil with $1000 \mathrm{ml}$ of tap water and continuously stirred for two hours at $30^{\circ} \mathrm{C}$; the supernatant was filtrated through a Whatman No. 1 filter after soil particles setting. Subsequently, the extract was sterilized by filtering through $0.22 \mu \mathrm{m}$ pore size membrane filters and stored at room temperature. $\mathrm{pH}$ of the extract is maintained between 9 and 10 . The inoculated media were incubated at three temperatures $(30,35$, $40^{\circ} \mathrm{C}$ ) for $7 \mathrm{~d}$. After that, the single colonies of actino bacteria which surrounded by clear zone and non-forming clear zone were chosen, and then re-cultured in the same medium. The pure bacterial isolates were maintained in nutrient agar slants and maintained at $4^{\circ} \mathrm{C}$.

Primary screening for extracellular keratinolytic proteases After primary identification of these isolates depending on morphological characteristics, including microbial and cultural features as well as an oxidase and catalase tests $[26,27]$, they were subjected to detect their ability to produce extracellular proteases and antibiotics using selective media.

\section{Proteolytic activity}

This test was studied with skimmed milk (Hi-media) medium at pH 9, ISP2 medium supplemented with $2 \%$ skimmed milk. The plates were inoculated and incubated at $35^{\circ} \mathrm{C}$. The hydrolysis clear zone appeared around actinobacterial colonies were recorded after 7-10d of incubation $[26,28]$.

\section{Keratinase activity}

This test was studied with two different media, including feather meal agar and liquid native feather media, the feather meal agar was composed of $1 \%$ of the feather meal, $1 \%$ glucose, and $0.02 \mathrm{mM}$ glycine buffer at final $\mathrm{pH}$ 9. Each actinobacterial isolate was cultured on sterile medium plates separately and then incubated at $35^{\circ} \mathrm{C}$ for $7 \mathrm{~d}$. The feather meal hydrolysis were observed visually by the presence clear zone around the producing colonies. The keratinase producing colonies on the plate were isolated and inoculated into liquid feather-media supplemented with a native feather as a sole carbon and nitrogen source. The modified liquid native feather medium contained the following constituents (g/l): $\mathrm{NaCl}(0.5), \mathrm{KH}_{2} \mathrm{PO}_{4}(0.7), \mathrm{K}_{2} \mathrm{HPO}_{4}(1.4), \mathrm{MgSO}_{4}(0.1)$, and native feather (100). The $\mathrm{pH}$ of the media was adjusted to 7, 9, and 11 using sodium carbonate. $50 \mathrm{ml}$ tubes containing $25 \mathrm{ml}$ medium were used and inoculated with $5 \%$ of culture suspensions (OD 0.5 at $600 \mathrm{~nm}$ ) for each isolate separately. Subsequently, the inoculated feather medium was incubated at $35^{\circ} \mathrm{C}$ for $10-14 \mathrm{~d}$. The feathers were degraded intensively by the purified isolates that confirmed by microscopic examination or by converting the medium of native feather completely to a clear state after $14 \mathrm{~d}$. The pure cultures were maintained on casein agar plate slants at $4^{\circ} \mathrm{C}$ for further work

\section{Primary screening for antagonistic activity}

Preliminary screening for antibacterial activity was done by the cross-streak method [29] on Mauler-Hinton agar. Actino bacterial isolates were streaked across one-third of the plates and the plates incubated at $30^{\circ} \mathrm{C}$ for $10 \mathrm{~d}$, after that the test bacteria (Staphylococcus aureus and Pseudomonas aeruginosa) were streaked perpendicular to the actino bacteria, and the plates were further incubated at $37^{\circ} \mathrm{C}$ for $24 \mathrm{~h}$. The inhibitory effect was determined by the failure of test bacteria to grow near producing actino bacteria.

The test organisms obtained from Biotechnology and Genetic Engineering Laboratory at the University of Babylon, Hillah, Iraq.

\section{Phenotypic and molecular identification of potential isolate}

The selected isolate (28ROR) which appeared a potent bioactive metabolite was identified depending on the basis of their microbial, physiological, and biochemical characteristics according to the methods that mentioned in Bergey's Manual of Systematic Bacteriology [27] and related references $[25,26]$.

The molecularidentification of the isolate including isolation of genomic DNA of actinobacterial culture, partial $16 \mathrm{~S}$ rRNA gene amplification, DNA sequencing, and phylogenetic analysis, these experiments was carried out at Izmir Institute of Technology, Biotechnology Bioengineering Research and Application Center (BIYOMER), Izmir, Turkey.

The 28ROR isolate was cultured in Luria-Bertani agar (Sigma-Aldrich, USA) for a week at $30^{\circ} \mathrm{C}$. Genomic DNA was extracted using Gene Jet ${ }^{\mathrm{TM}}$ GenomicDNA purification Kit (Fermentas Scientific, Inc.) according to manufacturer's instructions. The concentration of DNA and purity were 
measured using the Nanodrop ND 1000 spectrophotometer (Fermentas Scientific, Inc.). The extracted DNA was kept at $-20^{\circ} \mathrm{C}$ in aliquots.

Polymerase chain reaction (PCR) reactions were conducted using the iCycler Thermal Cycler (Bio-Rad, USA Laboratories, Inc. 16S rDNA genes were amplified using the specific primers for archaea A751F/UA1406R (Table 1) (Centromere DNA Technologies LTD., Istanbul, Turkey) based on the mentioned reference [30], the reaction mixture was set up in $25 \mu$ final reaction volume (Table 2). PCR recipe and cyclic conditions were optimized, the cyclic conditions: Pre-denaturation at $95^{\circ} \mathrm{C}$ for $10 \mathrm{~min} ; 35$ cycles of denaturation at $94^{\circ} \mathrm{C}$ for $2 \mathrm{~min}$, annealing at $52.3^{\circ} \mathrm{C}$ for $1 \mathrm{~min}$, and extension at $72^{\circ} \mathrm{C}$ for $1 \mathrm{~min}$; final extension at $72^{\circ} \mathrm{C}$ for $10 \mathrm{~min}$ followed by holding at $4^{\circ} \mathrm{C}$. A $10 \mu \mathrm{l}$ of the amplicon was checked by electrophoresis through $0.8 \%$ agarose gel.

The purified PCR product of 28ROR isolate was subjected to the sequencing reactions according to the manufacture's recommendation using the BigDyeR Terminatorv3. 1sequincing reaction Kit (Applied Biosystems, Foster City, CA, USA). The reaction mixture was set up in $10 \mu$ final reaction volume ( $4 \mu \mathrm{l}$ of Purified PCR product $(\sim 25 \mathrm{mg}), 1 \mu \mathrm{l}$ of Primer (3.2 pmol/ $\mu \mathrm{l}), 1 \mu \mathrm{l}$ of $(5 \times)$ BigDye Sequencing Buffer, $4 \mu \mathrm{l}$ of BigDye Terminator v3. 1 ready reaction mix) in thin-wall tube and all reagents were kepton ice during the experiment. The primer UA1406R was used for partial 16S rRNA gene sequencing of actino bacteria. The reaction tubes were transferred to the BioRad C1000 ThermalCycler (BioRad, USA Laboratories, Inc.). The sequencing reaction and cycle conditions were optimized as the following: Predenaturation at $98^{\circ} \mathrm{C}$ for $5 \mathrm{~min}$; 30 cycles of (denaturation at $96^{\circ} \mathrm{C}$ for $20 \mathrm{~s}$, annealing at $56^{\circ} \mathrm{C}$ for $10 \mathrm{~s}$, extension temperature $60^{\circ} \mathrm{C}$ for $4 \mathrm{~min}$ ); final extension at $60^{\circ} \mathrm{C}$ for $5 \mathrm{~min}$ then hold at $4^{\circ} \mathrm{C}$. The BigDye Terminator ready reaction mix was added after the pre-denaturation step. The sequencing product was purified using Sephadex G-50 (Sigma-Aldrich) through the spin column. The tubes were spinning at $5400 \mathrm{rpm}$ for $2 \mathrm{~min}$ and DNA was collected. The collected DNA was transferred the ABI Prism 3130XL Genetic Analyzer (Applied Biosystems, Foster City, CA, USA) for the recording of a sequence.

Sequencing results were analyzed for chimeras using DECIPHER version 1.4.0 program [31] for 16S rRNA gene (We introduce DECIPHER (http://DECIPHER.cee.wisc.edu), a publicly available web-based tool specific for detection of chimeric $16 \mathrm{~S}$ rRNA sequences with the use

Table 1: Primers used in this study

\begin{tabular}{lllll}
\hline Primer name & Sequence 5 $\rightarrow \mathbf{3}^{`}$ & $\mathbf{T}_{\mathbf{m}}$ & Matches & Ref. \\
\hline A751F & GCYTAAAGSRICCGTAGC & 52 & 675 & 37 \\
UA1406R & ACGGGCGGTGWGTRCAA & 52 & 17237 & 37 \\
\hline
\end{tabular}

Table 2: Components of a single $25 \mu$ PCR master mix

\begin{tabular}{lll}
\hline Reagent & Volume $(\mu \mathrm{l})$ & $\begin{array}{l}\text { Final } \\
\text { concentration }\end{array}$ \\
\hline Water (sterile, nuclease-free) & 12.925 & \\
10×PCR buffer (Fermentas) & 2.50 & $1 \mathrm{X}$ \\
MgCl $_{2}$ (25 mM) (Fermentas) & 1.00 & $1 \mathrm{mM}$ \\
dNTP mixture (25 mM each) & 0.20 & $0.2 \mathrm{mM}$ \\
(Fermentas) & & \\
Primer A751F (10 mM) & 0.50 & $0.2 \mathrm{mM}$ \\
Primer UA1406R (10 mM) & 0.50 & $0.2 \mathrm{mM}$ \\
Taq DNA polymerase (recombinant) & 0.125 & $0.03 \mathrm{U} / \mathrm{ml}$ \\
(5 U/ml) (Fermentas) & & \\
Betaine (12.5 M) (Sigma-Aldrich, & 2.00 & $1 \mathrm{M}$ \\
USA) & & \\
BSA (10 mg/ml) (Sigma-Aldrich, & 0.25 & $0.1 \mathrm{mg} / \mathrm{ml}$ \\
USA) & & \\
DNA template (20-40 ng/ml) & 5.00 & $0.8-1.6 \mathrm{ng} / \mathrm{ml}$ \\
Total & 25 & \\
\hline
\end{tabular}

PCR: Polymerase chain reaction, BSA: Bovine serum albumin of the novel search-based approach. For standalone implementations, the DECIPHER R package, source code, and associated documentation are available for download under the terms of the GNU (General Public License.).

Sequences similarity was accomplished through sequence alignment to the existing relevant sequences available in database at National Center for Biotechnology Information (NCBI) using the Basic Local Alignment Search Tool (BLAST) program: BLASTN 2.5.0+ [32] Biotechnology information (http://www.ncbi.nlm.nih.gov) online gene database to determine taxonomic classification through finding the most similar sequence in the database to the isolated species and its significant polygenetic relationship represented by similarity percentage. A phylogenetic neighbor-joining tree was constructed in MEGA version 7 software [33,34] using the method of Saitou and Nei [35].

\section{Preparation of soluble keratin and keratinase activity assay}

Keratinolytic activity was measured with soluble keratin $(0.5 \%$, $\mathrm{w} / \mathrm{v}$ ) as substrate. Soluble keratin was prepared from white chicken feathers by the method of Wawrzkiewicz et al. [36] with some modification. Defatting chicken feathers $(10 \mathrm{~g})$ in $500 \mathrm{ml}$ of dimethyl sulfoxide were heated in a reflux condenser at $100^{\circ} \mathrm{C}$ for $2 \mathrm{~h}$. Soluble keratin was then precipitated by adding $40 \%$ saturation ammonium sulfate and $200-300 \mathrm{ml}$ cold acetone at $-20^{\circ} \mathrm{C}$, mixed well by vortex, leave to stand for 30-60 min on ice-bath, then centrifuged at $4{ }^{\circ} \mathrm{C}$ and $10,000 \mathrm{rpm}$ for $15 \mathrm{~min}$, followed three phase formation, the salt phase (lower layer), acetone (upper layer), and the protein layer floated within acetone phase. Protein precipitate was separated by cooling centrifugation at $10,000 \times \mathrm{g}$ for $10 \mathrm{~min}$. The resulting precipitate was washed four times with distilled water and dried at $35^{\circ} \mathrm{C}$ in the oven overnight. One gram of quantified precipitate was dissolved in $20 \mathrm{ml}$ of $0.05 \mathrm{~mol} / \mathrm{l} \mathrm{NaOH}$. The $\mathrm{pH}$ was adjusted to 8.5 with $0.1 \mathrm{~m}$ Tris and $0.1 \mathrm{~mol} / \mathrm{l} \mathrm{HCl}$ and the solution was diluted to $200 \mathrm{ml}$ with $0.05 \mathrm{~m}$ Tris-HCl buffer ( $\mathrm{pH} 8.5$ ).

Keratinolytic activity was assayed with soluble keratin as a substrate, according to the method of Wawrzkiewicz et al. [36]. An enzyme solution $(1.0 \mathrm{ml})$ was mixed with $1.5 \mathrm{ml}$ of $0.05 \%(\mathrm{w} / \mathrm{v})$ soluble keratin in $0.1 \mathrm{M}$ Tris buffer ( $\mathrm{pH} \mathrm{8.5)}$ ) and incubated for $3 \mathrm{hrs}$ at $30^{\circ} \mathrm{C}$. The reaction was terminated by adding $1.0 \mathrm{ml}$ of $5 \%(\mathrm{w} / \mathrm{v}$ ) trichloroacetic acid (TCA) and centrifuged at $10,000 \mathrm{rpm}$ for $10 \mathrm{~min}$ at $4^{\circ} \mathrm{C}$. The absorbance of the supernatant was measured at $280 \mathrm{~nm}$. The control was prepared by incubating the enzyme solution with $1.0 \mathrm{ml}$ TCA for 5 minutes after that keratin solution was added. One unit (U) of keratinolytic activity was defined as the amount of enzyme that resulted in an increase in absorbance at $280 \mathrm{~nm}$ with the control for 0.001 per min under the conditions described above. The control was prepared by incubating the enzyme solution with $1.0 \mathrm{ml}$ TCA for $5 \mathrm{~min}$ after that keratin solution was added. The keratinolytic activity was calculated by the following equation:

$$
\text { Enzyme unit }(\mathrm{U} / \mathrm{ml})=\frac{\text { Absorbance } 280 \mathrm{~nm}}{0.001 \times \text { reaction time }(\min ) \times \text { enzyme volume }} \times \mathrm{n}
$$

Protein concentration was estimated according to the Bradford method [37] by using the bovine serum albumin as a standard.

\section{Optimizing the production of extracellular keratinase}

The effect of various parameters such as $\mathrm{pH}$, production media components, temperature, and incubation times on keratinase production was studied by varying a single parameter at a time. All experiments were performed in $50 \mathrm{ml}$ bacterial culture tubes, each one containing $25 \mathrm{ml}$ of the medium, in triplicated. All media were sterilized by autoclave at $121^{\circ} \mathrm{C}$ for $20 \mathrm{~min}$. The tubescontaining media were inoculated with $5 \%$ of culture suspensions (OD 0.5 at $600 \mathrm{~nm}$ ) of the actinobacterial strain (28ROR) inoculum. The inoculum was prepared as a seed culture that was grown under optimal growth conditions (ISP2 broth at $\mathrm{pH} 8.5$ and incubated at $30^{\circ} \mathrm{C}$ for $4 \mathrm{~d}$ ). After that, the cell-free filtered supernatant was separated from the culture broth by 
filtration, and then it was filtered by Millipore filter $(0.22 \mu \mathrm{m})$. Enzyme activity and protein concentration were estimated [36,37]

Keratinase was produced from the actinobacterial strain (28ROR) using liquid medium contained $10 \%$ intact defatted feather, $1 \%$ glucose, yeast extract $(0.1 \%), \mathrm{NaCl}(0.5 \%), \mathrm{KH}_{2} \mathrm{PO}_{4}(0.07 \%), \mathrm{K}_{2} \mathrm{HPO}_{4}(0.14 \%)$, $\mathrm{MgSO}_{4} .7 \mathrm{H}_{2} \mathrm{O}(0.05 \%)$, and $0.3 \% \quad \mathrm{Na}_{2} \mathrm{CO}_{3}$ (separately autoclaved), $\mathrm{pH} 9$ [26]. The insulated tubes containing $25 \mathrm{ml}$ of liquid media were incubated at $35^{\circ} \mathrm{C}$ for $7-14 \mathrm{~d}$. When the feather hydrolysis visually observed, the enzyme was harvested using filtration. After that, enzyme activity and protein concentration were estimated [36,37].

The optimal feather meal concentration was determined using different concentrations of feathers ranged $1-10 \%$ were added to the Erlenmeyer flask containing production medium, the ratio of liquid medium volume to flask volume was $1 / 5$. These media were inoculated, in triplicate, with the actinobacterial inoculum and incubated at $35^{\circ} \mathrm{C}$ for $7-14 \mathrm{~d}$. Subsequently, the enzyme activity and protein concentration were estimated after enzyme harvested [36,37].

To study the effects of medium components, four type media at $\mathrm{pH} 10$ (Table 3) were used to produce the enzyme from the actinobacterial strain 28ROR, the inoculated media, in triplicate, were incubated at $35^{\circ} \mathrm{C}$ for $7-14 \mathrm{~d}$. The enzyme activity and protein concentration were estimated after enzyme harvested [36,37].

The effect of pHs on the enzyme production was studied, in triplicate. The production medium was adjusted at different pHs (6-12) with $0.05 \mathrm{M}$ available buffer, including citrate buffer at $\mathrm{pH}$ 6, Tris buffer at pH 7 and 8, and glycine buffer at pH 9 and 10, carbonate buffer at pH 11 and 12 . After the sterilized media inoculation with $5 \%$, the bacterium seeding (OD 0.5 at $600 \mathrm{~nm}$ ) were incubated at $35^{\circ} \mathrm{C}$ for $7-14 \mathrm{~d}$. The enzyme activity and protein concentration were estimated [36,37], after enzyme harvested.

To optimize the optimal production temperature, the inoculated optimal media, in triplicate, were incubated at different temperatures ranged from $20-45^{\circ} \mathrm{C}$ for $7-14 \mathrm{~d}$, after that the enzyme was harvested using filtration, and then the enzyme activity and protein concentration were estimated [36,37].

\section{Data analysis}

Data were analyzed using SPSS version 22 software Fisher's exact and t-test and ANOVA one-way with a significant $\mathrm{p}<0.05$.

Table 3: The components of production media

\begin{tabular}{lllll}
\hline $\begin{array}{l}\text { Media } \\
\text { components (g/l) }\end{array}$ & Peptone & $\begin{array}{l}\text { Yeast } \\
\text { extract }\end{array}$ & Mineral & $\begin{array}{l}\text { Cement } \\
\text { extract }\end{array}$ \\
\hline Feather meal & 10.0 & 10.0 & 10.0 & 10.0 \\
$\mathrm{MgSO}_{4} .7 \mathrm{H}_{2} \mathrm{O}$ & 0.5 & 0.5 & 0.5 & 0.0 \\
$\mathrm{KH}_{2} \mathrm{PO}_{4}$ & 0.7 & 0.7 & 0.7 & 0.0 \\
$\mathrm{~K}_{2} \mathrm{HPO}_{4}$ & 1.4 & 1.4 & 1.4 & 0.0 \\
$\mathrm{NaCl}$ & 10.0 & 10.0 & 10.0 & 0.0 \\
$\mathrm{Na}_{2} \mathrm{CO}_{3}{ }_{\text {a }}$ & 3.0 & 3.0 & 3.0 & 0.0 \\
Yeast extract $^{\text {Yeast }}$ & 0.0 & 0.0 & 0.0 & $0.15-0.30^{c}$ \\
Peptone & 0.0 & 5.0 & 0.0 & 0.0 \\
Distilled water (l) & 5.0 & 0.0 & 0.0 & 0.0 \\
Tap water (l) & 1.0 & 10.0 & 10.0 & 0.0 \\
\hline
\end{tabular}

${ }^{a}$ All media components were sterilized by autoclave $121^{\circ} \mathrm{C}(1.5$ bars $)$ for $20 \mathrm{~min}$ except $\mathrm{Na}_{2} \mathrm{CO}_{3}$ was autoclaved separately and mixed with the other components after cooling to $45^{\circ} \mathrm{C}$ and cement extract was sterilized by filtration. ${ }^{\mathrm{b}} \mathrm{Cement}$ extract was prepared by suspending $250 \mathrm{~g}$ of regular Portland cement in one liter of tap water and continuously stirred for $2 \mathrm{~h}$ at $30^{\circ} \mathrm{C}$; the supernatant was filtrated through a Whatman No. 1 filter after cement particles setting Subsequently, the extract was sterilized by filtering through $0.22 \mu \mathrm{m}$ pore size membrane filters and stored at room temperature. The $\mathrm{pH}$ of the extract is maintained between 9 and 10 [26]. 'The $0.30 \mathrm{l}$ was added to the medium at $\mathrm{pH} 10$ and $0.15 \mathrm{l}$ of the medium at $\mathrm{pH} 6$

\section{RESULTS}

\section{Primary screening of keratinases and active metabolites} production

In this study, thirty actinobacterial isolates were recovered from 55 samples were collected from different sources, including,14 isolates recovered from the farm soils (the isolates 1-14); 9 isolates from the waste chicken feathers (the isolates 15-23); and 7 isolates recovered from soils of poultry farm (the isolates 24-30). The purified isolates colonies appeared different morphology and color of aerial and substrate mycelia. They were Gram-positive filament cells, also some of biochemical characterizations were performed.

The extracellular protease productions were screened from actinobacterial isolates and the results revealed that $22(73.3 \%)$ out of thirty actinobacterial isolates appeared the ability to produce extracellular alkaline protease enzymes on milk agar at pH 9 (Fig. 1a). Of 22 of actinobacterial isolates, only 11 (50\%) appeared keratinolytic activities in feather meal agar medium (Fig. 1b), and able to efficiently utilize feather as a source of carbon and nitrogen. Four isolates $(5,6,17$ and 28 ) showed a significant $(\mathrm{p}<0.05)$ alkaline protease productions, whereas the isolate 28 showed a significant $(\mathrm{p} \leq 0.001$ at a level 0.95 CIP) keratinase production on feather meal agar and in liquid native feather medium (Fig. 2). Therefore, the isolate 28 was selected to produce extracellular keratinase enzyme. From these results, not all proteolytic enzymes (50\%) had keratinolytic activities.

The ability of produce antimicrobial metabolites from protease producing actinobacterial isolates were investigated, only $22.7 \%$ of the isolates appeared antibacterial activity against $S$. aureus and $10 \%$ of isolates against $P$. aeruginosa and the isolate 28 was the best.

\section{Phenotypic and molecular identification of potential isolate}

The potential isolate 28 which recovered from poultry farm soil, it was aerobic and Gram-positive actinobacteria and colonies were the wrinkled appearance to folded on ISP2 medium and it formed dirty white aerial mycelium (Fig. 3b), becoming light yellowish gray in old cultures on glucose-yeast extract-malt extract medium. Hyphae of the aerial mycelium are straight to flexuous. In older cultures, hyphae of aerial mycelium disintegrate into spore-like structures. It had not the ability to produce endo- or exopigments. Melanoid pigments were not produced in ISP6 medium. It had the ability to grow at different temperatures ranged from $10^{\circ} \mathrm{C}$ to $45^{\circ} \mathrm{C}$, but not at $50^{\circ} \mathrm{C}$. Optimal growth was obtained on glucose yeast extract-malt extract agar at $28-30^{\circ} \mathrm{C}$. It is capable of growing within a wide range of pHs (6-12), but not lower than $\mathrm{pH} 5$ and the optimum $\mathrm{pH}$ 9. It tolerated salinity until $10 \%(\mathrm{w} / \mathrm{v}) \mathrm{NaCl}$. It had the ability to utilize carbon sources like L-arabinose, galactose, glycerol, inositol, d-lactose, mannitol, d-mannose, L-rhamnose, sucrose, and d-xylose. Furthermore, it was positive to catalase test, it hydrolyzed starch and degrade protein sources such as casein, keratin, and poultry feathers (Fig. 3a and c) by producing a keratinolytic protease. As well as this isolate produced antibacterial and antifungal metabolites. From the above results, the isolate 28 regarded to genus Nocardiopsis [27].

The molecular identification of the isolate 28 using partial sequencing of the 16S rRNA gene and the phylogenetic tree was constructed by the neighbor-joining method for comparison of the 16S rRNA gene sequences, indicated that the strain belonged to the genus Nocardiopsis. The levels of similarity between the 16S rRNA gene of Nocardiopsis species are shown in Fig. 4. The NCBI sequence data show that the isolate had $100 \%$ similarity with Nocardiopsis aegyptia SNG49 strain and $99 \%$ with other Nocardiopsis species of the phylogenic tree (Fig. 4). No chimeric sequences detected. The sequence had been deposited and registered in the GenBank database under the accession number KC702802.1 and named Nocardiopsis sp. 28ROR. In spite of the isolate $28 \mathrm{ROR}$ was similar (100\%) to Nocardiopsis egyptian SNG49 strain, but it is located in another cluster and it's neighboring to Nocardiopsis dassonvillei DSM 43111 strain, that may be indicated, it is a new strain. 


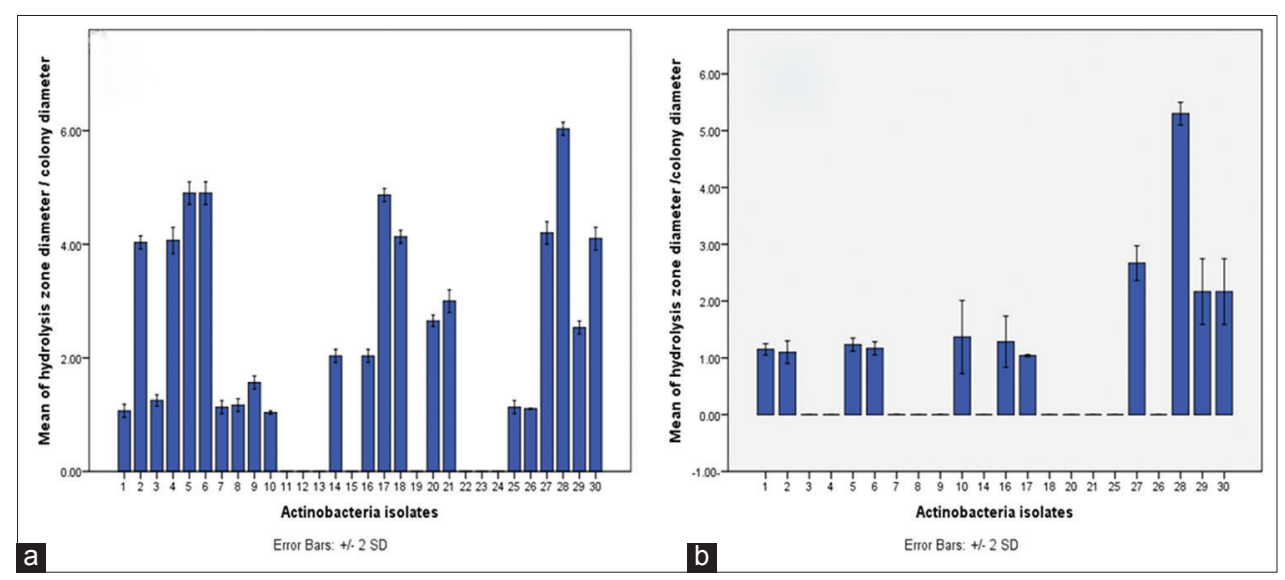

Fig. 1: Primary screening of extracellular alkaline proteases and keratinolytic activities of producing actinobacterialisolates. (a) Milk agar, (b) Feather meal agar at $\mathrm{pH} 9$ and incubated at $35^{\circ} \mathrm{C}$ for $\mathbf{7 d}$

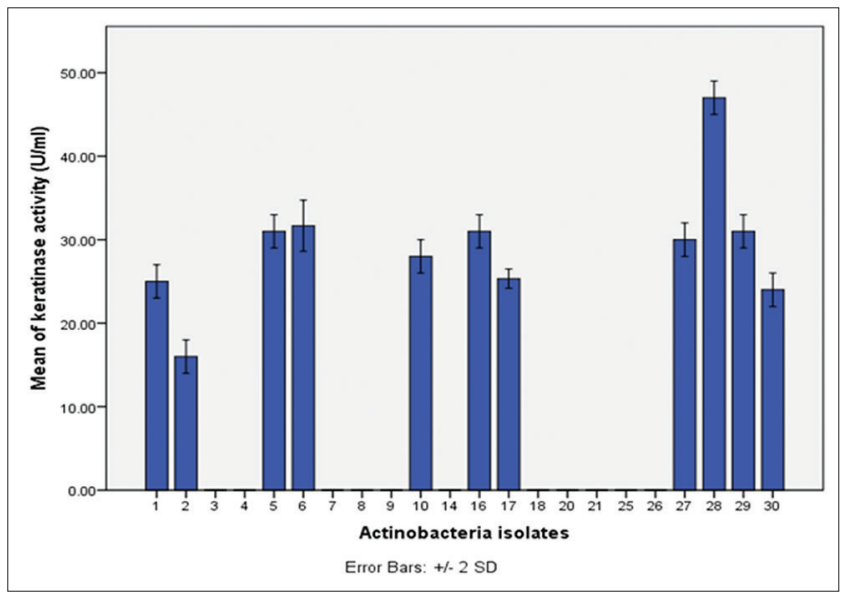

Fig. 2: Secondary screening of extracellular keratinolytic activities of producing actinobacterial isolates in liquid native feather medium at $\mathrm{pH} 9$ and incubated at $35^{\circ} \mathrm{C}$ for $7 \mathrm{~d}$

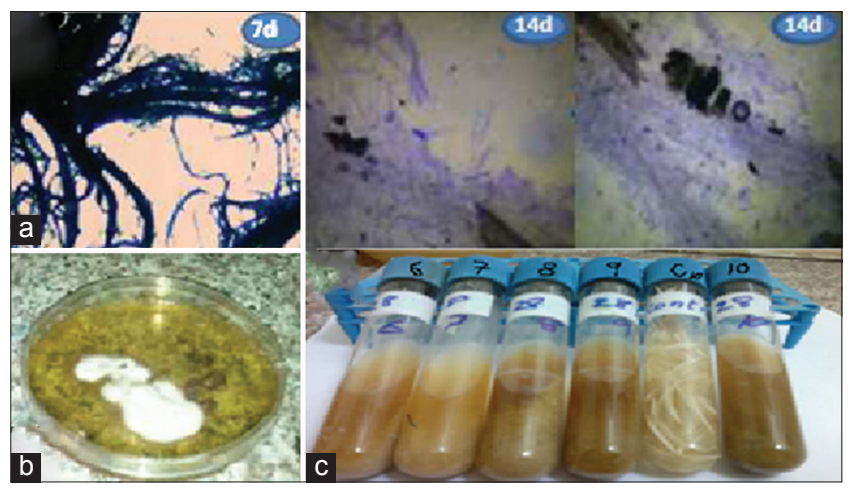

Fig. 3: Keratinolytic activity of Nocardiopsis sp. 28ROR. ${ }^{2}$ Degradation of a native chicken feather by Nocardiopsis sp. 28ROR after 7-14 d. bolonies of Nocardiopsis sp. 28ROR on potato dextrose agar medium, incubated at $35^{\circ} \mathrm{C}$ for $5 \mathrm{~d}$. 'Degradation of a native chicken feather $(10 \%)$ at a range of $\mathrm{pHs}(6-10)$ by the isolate at $35^{\circ} \mathrm{C}$ for $28 \mathrm{~d}$

Optimizing of some production parameter of keratinolytic protease from Nocardiopsis sp. 28ROR

The previous preliminary experiments revealed that the strain 28ROR produced extracellular keratinolytic protease, it began after three days during the post-exponential phase of growth and it continued until $14 \mathrm{~d}$ during stationary phase, after that, it reduced gradually until the native feather was completely degraded. Also, this strain degraded feather at a wide range of initial $\mathrm{pHs}$, and the exclusively degradation occurred at initial $\mathrm{pH} 6$ and $\mathrm{pH} 10$, therefore these two $\mathrm{pH}$ values were selected to study other cultural parameters such as production media components and temperature. In these experiments the native feathers were replaced by feather meal to enhance enzyme production with short interval time because of the native feather was more complex, which composed of keratin protein and covered with wax and fats, that must be firs degraded to facilitate keratinolytic protease to reach the keratin layer.

The effect of feather meal concentration on the enzyme production was investigated by using different concentrations ranged from $1 \%$ to $10 \%$. The results appeared that the low concentrations of feather meal $(1-2 \%)$ were best from the higher concentrations and they were degraded completely during 10-14 d in comparison with high concentrations which required a long time more than $28 \mathrm{~d}$, and the degradation occurred gradually (Fig. 5). In addition to the keratinase production levels were higher at low concentration of feather meal, because of the production of keratinase. As a result, $1 \%$ feather meal was selected to complete the next experiments.

The effect of media components was studied using four media, including feather-peptone, feather-yeast extract, feather-minerals and feather-cement extract media (Fig. 6). The results revealed that feathermineral medium was the best for enzyme production at $\mathrm{pH} 6 \mathrm{(p=0.035}$ at a level 95\%) from Nocardiopsis sp. 28ROR, whereas both feathermineral and feather-cement extract media were the best to produce the enzyme at $\mathrm{pH} 10, \mathrm{p}=0.01$ and $\mathrm{p}=0.009$ respectively. As a result, the minerals medium was selected to complete next experiments.

The effect of various additional nitrogen sources on keratinase production, in media containing $10.0 \mathrm{~g} / \mathrm{l}$ of chicken feather meal as a carbon source, was also carried out (Fig. 6). The addition of yeast extract or peptone to the medium containing feather meal as an additional nitrogen source did not enhance keratinases production and supported lower levels compared to the medium as a control (mineral medium) containing only feather meal as a carbon and nitrogen source. Furhermore, in the present study, cement extract was used as a source of minerals and high alkaline buffer to prevent the initial $\mathrm{pH}$ value changes by the by-products of microorganism.

To get the best keratinase production, the initial $\mathrm{pH}$ of selected media (feather mineral medium) was re-optimize using buffer systems ranged from 6 to 12. The results also revealed that the presence two $\mathrm{pH}$ values $(6$ and 10$)$ for the highest enzyme production $(\mathrm{p}<0.05$ at a level 95\%) (Fig. 7). This result may be indicated that the isolate 28ROR had the ability to produce two different keratinases (acid and alkaline keratinolytic protease) which induced at the two different $\mathrm{pH}$ values. 


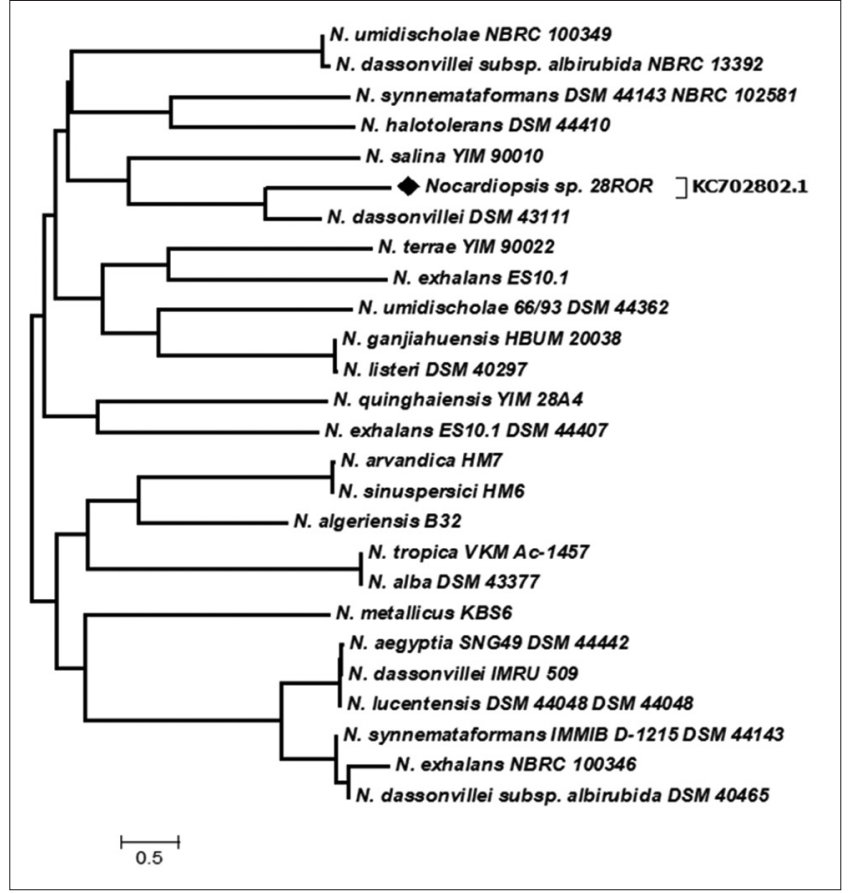

Fig. 4: Phylogenetic tree based on $16 \mathrm{~S}$ rRNA gene, partial sequences of the actinobacterial strain 28ROR (GenBank: KC702802.1). The evolutionary history was inferred using the Neighbor-Joining method [33]. The evolutionary distances were computed using the maximum composite likelihood method [32]. The scale bar represents the number of substitutions per site. The analysis involved 26 nucleotides sequence and evolutionary analyses were conducted in MEGA7 [34]

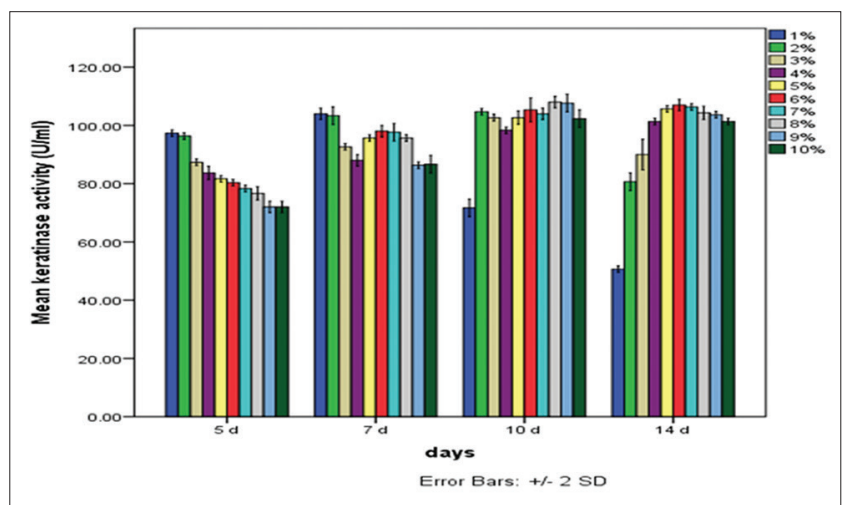

Fig. 5: The effect of feather meal concentrations on keratinase production. The production medium containing various feather meal concentrations (1-10\%), the growth conditions of Nocardiopsis sp. $28 \mathrm{ROR}$ were $35^{\circ} \mathrm{C}, \mathrm{pH}$ 6, for $14 \mathrm{~d}$

Furthermore, the optimal production temperature appeared two values at $30-35^{\circ} \mathrm{C}(\mathrm{p}=0.004)$ in the feather mineral medium at $\mathrm{pH} 6$ and $40^{\circ} \mathrm{C}$ (Fig. 8), followed $35^{\circ} \mathrm{C}$ by the medium at $\mathrm{pH} 10 \mathrm{p}=0.005$ and $\mathrm{p}=0.015$ respectively). If we thought it was a single or the same enzyme and the isolate (Nocardiopsis sp. 28ROR) had ability to modulate its micro-environment by secreted acid or alkaline metabolite with the enzyme, but the final $\mathrm{pH}$ of the culture filtrates were slightly changed about $1 \pm 0.5 \mathrm{pH}$ value because of the medium containing buffer minerals, that means the isolate produced two types of enzyme, acid, and alkaline also these enzymes had optimum activities at the different $\mathrm{pH}$ values of production. As a result the optimum conditions of production acid keratinolytic protease in feather mineral medium containing $1 \%$ feather meal at $\mathrm{pH} 6,30-35^{\circ} \mathrm{C}$ for $7 \mathrm{~d}$, and the alkaline

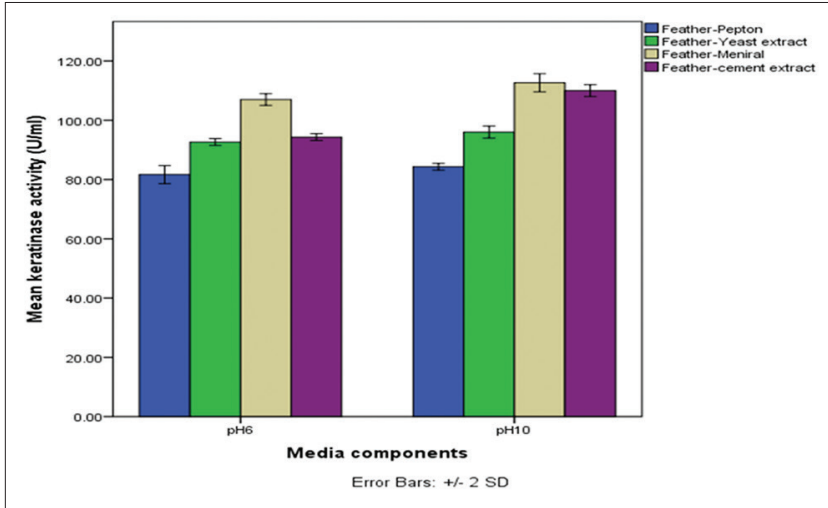

Fig. 6: The effect of media components on keratinase production from Nocardiopsis sp. 28ROR. The media were prepared at pH 6 and 10 , and the growth conditions were $35^{\circ} \mathrm{C}$ for $7 \mathrm{~d}$

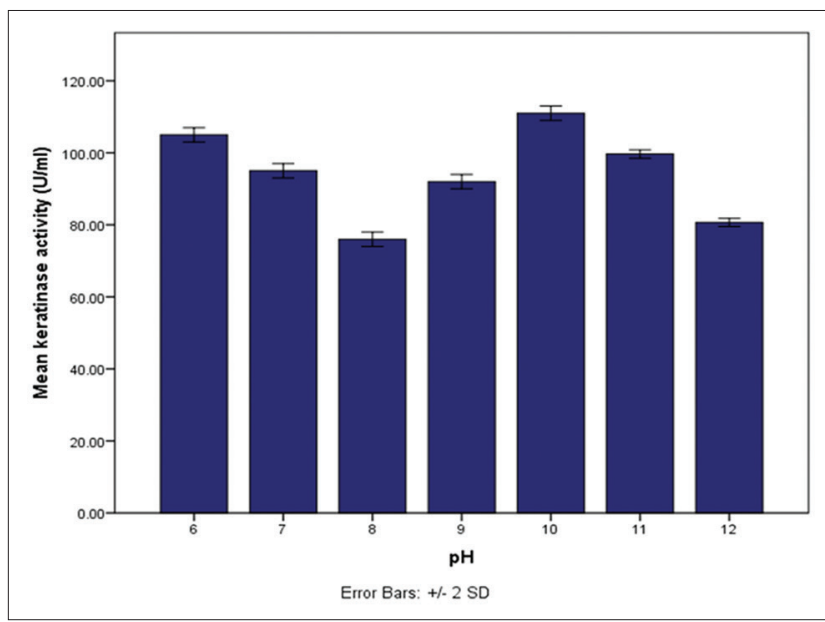

Fig. 7: The effect of initial $\mathrm{pH}$ values of feather mineral medium on keratinase production from Nocardiopsis sp. $28 \mathrm{ROR}$ at $35^{\circ} \mathrm{C}$ for $\mathbf{7} \mathbf{d}$

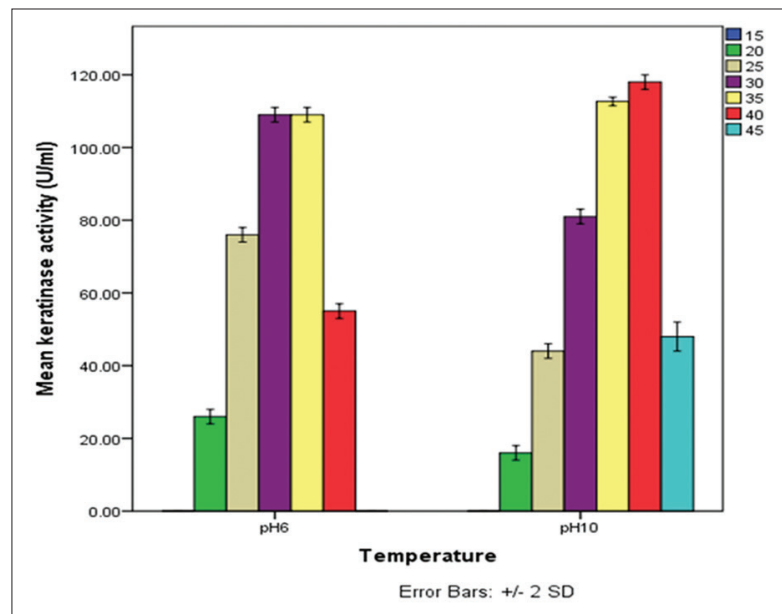

Fig. 8: The effect of incubation temperature on keratinase production from Nocardiopsis sp. 28ROR. The enzyme fermentation conditions occurred in feather mineral medium at two $\mathrm{pH}$ values ( 6 and 10 ) for $7 \mathrm{~d}$

keratinolytic protease in feather mineral medium or feather mealcement extract medium containing $1 \%$ feather meal at $\mathrm{pH} 10,40^{\circ} \mathrm{C}$ for $7 \mathrm{~d}$. 


\section{DISCUSSION}

Actinobacterial species are associated with soil, and no certain enrichment or isolation procedures have been recommended for actinobacterial species and the isolation protocols described for Streptomycetes are commonly used. Most strains grow readily on a variety of media, especially those recommended by the ISP; those that have proved to be most effective include yeast extract-malt extract (ISP medium 2), oatmeal (ISP medium 3), glycerol-asparagine (ISP medium 5), extract-peptone agars and most strains may be recovered from agar plates after incubation at $28-30^{\circ} \mathrm{C}$ for $7-14 \mathrm{~d}$, also these media used for cultural characterization of actinobacterial isolates [25,38,39]. Nocardiopsis species like other actinobacterial species, mainly associated with soils, and there are several studies reported that the organisms being an occurrence in terrestrial locations along with other actinobacterial species like Streptomyces sp. The obvious traits of this organism were required for $\mathrm{NaCl}$ or tolerance it [20]. It isolated from hypersaline locates such as soda lakes, salterns, marine ecosystem, some invertebrate enamels, insects, also it associated with some plants and their rhizospheres especially from tropical regions [15]. The soil and poultry feather waste samples were the vital sources to isolate keratinolytic producing bacteria $[3,40,41]$. Singh et al. [40] had been recovered 35 actinobacterial isolates from soil samples collected from the poultry farms, and found twenty-nine isolates that showed protease activity on skimmed milk agar and out of these isolates twenty-seven had keratinolytic activity. Many researchers used variant production feather media to produce keratinase enzyme [3-8]. The results of Singh et al. [40] were in agreement with our results which all our isolates were recovered from soil samples, including the potential isolate 28ROR that was recovered from the poultry farm soil sample.

Some of actinobacterial isolates had ability to produce antibacterial substances and these results consensus with previous studies that reportedthe actinobacterial species are the main sources for producing antimicrobial substances and the same organisms had the ability to produce antibacterial and antifungal substances [39,42-44]. The present study was focused on isolating the actinobacterial species had capability to produce keratinolytic proteases to degrade feather waste, with the aim of utilizing the product of degradation as carbon and nitrogen sources in antibiotic production.

The actinobacterial isolates were identified according morphological and biochemical characteristics also they identified according to the sequences of $16 \mathrm{~S}$ or $23 \mathrm{~S}$ rRNA genes, and then the phylogenetic tree was constructed by the neighbor-joining method for comparison of the 16S rRNA gene sequences [15-17,33-35]. Our isolate was characterized, identified, and recorded in the GenBank database under the accession number KC702802.1 and named Nocardiopsis sp. 28ROR. The phylogeny tree of the neighbor-joining of this actinobacterium was more related to $N$. dassonvillei DSM 43111 strain (99\%), in spite of it, had $100 \%$ similarity with $N$. aegyptia SNG49 strain that located in another cluster. In addition, the actinobacterium 28ROR was different from $N$. aegyptia SNG49 in some biochemical and cultural characteristics like growing at $45^{\circ} \mathrm{C}$, tolerate $10 \% \mathrm{NaCl}$ and it had the capability to grow at the wide range of pHs from 6 to 12 and the optimum $\mathrm{pH} 9$, and these characteristics were more similar to N. dassonvillei DSM 43111 strain $[27,45]$, that may be indicated, it is a new strain.

Many actinobacterial species had ability to produce extracellular proteases that degraded proteins to utilize as carbon and nitrogen sources. Feather keratin is one of the kinds of very complex and stiff proteins which only degrade by special type of proteases known keratinases. The previous studies that documented some of the actinobacterial species produced keratinolytic proteases such as Streptomyces sp. and Nocardiopsis sp. [5,15].

Any metabolite productions like the enzyme media must be contained carbon and nitrogen sources and basic minerals to enhance bacterial growth and induce extracellular enzyme production like proteases. These enzymes secreted from microorganisms to degrade the complex organic source like feather proteins to utilize the degradable soluble proteins (amino acids and amides) as carbon and nitrogen sources after consuming the simple nutrients from the microbial environments. The feather keratin as a raw waste was used as a substrate in the media for enzyme production to induce keratinolytic proteases synthesis; therefore these enzymes were used in recycling the poultry feather wastes [3-5]. To facilitate and improve the synthesis of keratinase in commercial productions or in the scientific research for enzyme purification and characterization, the raw feather waste was converted into feather meal by treating the feather with acids, alkalies or solvent compounds such as chloroform, methanol, and acetone to remove the outer layer of wax and fats [1,24]. As well as, the enzyme production level was higher by using feather meal as carbon and nitrogen sources in comparison with a native feather [46]. Some of the feather industries were performed by using solid state fermentation or submerge fermentation states with higher concentrations of feather more than $10 \%$ or $20 \%$, but these industries require long time more than one month to reach complete hydrolysis, therefore the feather meal was added to the media at limited concentrations up to $1-3 \%$ $[40,41,47]$. Because of some of the keratinase biosynthesis as inducible enzyme may be repressed partially or completely by the accumulation of free amino acid resulting from keratin degradation and the microorganism prefer utilizing simple nitrogen source, in addition to the keratinase production levels were higher at low concentration of feather meal [48]. On the other hand, some of the feather meal media supplemented with additional nitrogen sources such as peptone, yeast extract, ammonium nitrate to increase keratinase production, but not all proteases producers appeared positive response which may be decreased the enzyme production or repressed completely, due to the accumulation of simple sources of nitrogen like amino acids and amides. Our results are in agreement with Matikevičienè et al. [46] who estimated the addition of yeast extract, peptone and other nitrogen sources to media containing chicken feather meal which caused decrease or did not enhance the protease synthesis. Also, the production media supplemented with basic minerals, including buffer salts, to enhance bacterial growth, enzyme production and overcome the changing of the initial $\mathrm{pH}$ of media. In our study, cement extract was used as a source of minerals and it acts as a strong alkaline buffer to prevent the initial $\mathrm{pH}$ value changes by the byproducts of microorganisms. Because of the cement extract was rich with some alkaline minerals like calcium oxides and other metal oxides such as magnesium, ferric, aluminum and sulfurs [49]. The studied strain Nocardiopsis sp. 28ROR produced two types of keratinase (acid and alkaline) at different $\mathrm{pH}$ values ( 6 and 10 ) also the optimum activities of these enzymes at $\mathrm{pH} 6.0$ and 10.0. These results are in agreement with the previous references $[15,23,50]$ that documented the Nocardiopsis species were potential sources to produce bioactive metabolites and important extracellular enzymes. The alkaline proteases of $N$. prasina HA-4 had optimum activity at pH 7.0 and 10.0 and optimum temperature $55^{\circ} \mathrm{C}$ [50], the alkaline serine proteases of Nocardiopsis alba $0 \mathrm{~K}-5$ had optimum activity at $\mathrm{pH} 10.0$ and $80^{\circ} \mathrm{C}$ [51], also the alkaline serine proteases of $N$. dassonvillei NCIM 5124 had optimum pH $10.0-11.0$ and $60^{\circ} \mathrm{C}$ [52], and keratinolytic proteases produced from Nocardiopsis species SD5 and Nocardiopsis sp. TOA-1 had optimum activity at $\mathrm{pH} 9$ and $\mathrm{pH} 11.0-11.5$ and the temperature $50^{\circ} \mathrm{C}$ and $70-75^{\circ} \mathrm{C}$ respectively $[41,53]$.

\section{CONCLUSION}

The Nocardiopsis sp. 28ROR was a novel strain had the ability to produce two types of extracellular keratinases (acid and alkaline) in cheap feather waste medium. The wide tolerance of temperature and $\mathrm{pH}$ by Nocardiopsis sp. 28ROR keratinase makes it an ideal contender to be investigated further for potential application as a detergent additive,. in addition, the 28ROR strain had the ability to produce antibiotics and it could be formulated as acheap medium containing only minerals and feather meals as carbon and nitrogen sources. 


\section{ACKNOWLEDGMENTS}

I would like to thank my student Dr. Mohammad J. Khazal who performed the sequencing experiments at Izmir Institute of Technology Biotechnology Bioengineering Research and Application Center (BIYOMER), Izmir, Turkey.

\section{REFERENCES}

1. Mart'inez-Hernandez AL, Velasco-Santos C. Keratin fibers from chicken feathers: Structure and advances in polymer composites In: Dullaart R, Mousques J, editors. Keratin: Structure, Properties and Applications. New York: Nova Science Publishers; 2012. p. 149-211.

2. Fortier AM, Cadrin M. Simple epithelial keratins k8 and k18: From structural to regulatory protein. In: Dullaart R, Mousques J, editors. Keratin: Structure, Properties and Applications. New York: Nova Science Publishers; 2012. p. 1-35.

3. Kanchana R. Farm waste recycling through microbial keratinases. J Appl Sci Environ Sanit 2012;7(2):103-8.

4. Gopinath SC, Anbu P, Lakshmipriya T, Tang TH, Chen Y, Hashim U, et al. Biotechnological aspects and perspective of microbial keratinase production. Biomed Res Int 2015;2015:140726.

5. Gupta R, Ramnani P. Microbial keratinases and their prospective applications: An overview. Appl Microbiol Biotechnol 2006;70(1):21-33.

6. Kainoor PS, Naik GR. Production and characterization of feather degrading keratinase from Bacillus sp. JB 99. Indian J Biotechnol 2010;9:384-90.

7. Zaghloul TI, Embaby AM, Elmahdy AR. Biodegradation of chicken feathers waste directed by Bacillus subtilis recombinant cells: Scaling up in a laboratory scale fermentor. Bioresour Technol 2011;102:2387-93.

8. Vigneshwaran C, Shanmugam S, Sathish KT. Screening and characterization of keratinase from Bacillus licheniformis isolated from Namakkal poultry farm. Researcher 2010;2:89-96.

9. Hoq MM, Siddiquee KA, Kawasaki H, Seki T. Keratinolytic activity of some newly isolated Bacillus species. J Biol Sci 2005;5(2):193-200.

10. Joshi SG, Tejashwini MM, Revati N, Sridevi R, Roma D. Isolation, identification and characterization of a feather degrading bacterium. Int J Poult Sci 2007;6(9):689-93.

11. Xie F, Chao Y, Yang X, Yang J, Xue Z, Luo Y, et al. Purification and characterization of four keratinases produced by Streptomyces sp. Strain 16 in native human foot skin medium. Bioresour Technol 2010;101:344-50.

12. Riffel A, Brandelli A. Keratinolytic bacteria isolated from feather waste. Braz J Microbiol 2006;37(3):395-9.

13. Sapna R, Yamini V. Study of keratin degradation by some potential bacterial isolates from soil. J Soil Sci 2011;1(1):1-3.

14. Korniłłowicz-Kowalska T, Bohacz J. Biodegradation of keratin waste: Theory and practical aspects. Waste Manage 2011;31(8):1689-701.

15. Bennur T, Kumar AR, Zinjarde S, Javdekar V. Nocardiopsis species as potential sources of diverse and novel extracellular enzymes. Appl Microbiol Biotechnol 2014;98:9173-85.

16. Rainey FA, Ward-Rainey N, Kroppenstedt RM, Stackebrandt E. The genus Nocardiopsis represents a phylogenetically coherent taxon and a distinct actinomycete lineage: Proposal of Nocardiopsaceae fam. nov. Int J Syst Bacteriol 1996;46:1088-92.

17. Cook AE, Meyers PR. Rapid identification of filamentous actinomycetes to the genus level using genus-specific 16S rRNA gene restriction fragment patterns. Int J Syst Evol Microbiol 2003;53:1907-15.

18. Hamedi J, Mohammadipanah F, Pötter G, Spröer C, Schumann P, Göker M, et al. Nocardiopsis arvandica sp. nov. isolated from sandy soil. Int J Syst Evol Microbiol 2011;61:1189-94.

19. Hamedi J, Mohammadipanah F, von Jan M, Pötter G, Schumann P, Spröer C, et al. Nocardiopsis sinuspersici $\mathrm{sp}$. nov. isolated from sandy rhizospheric soil. Int J Syst Evol Microbiol 2010;60:2346-52.

20. Hamedi J, Mohammadipanah F, Ventosa A. Systematic and biotechnological aspects of halophilic and halotolerant actinomycetes. Extremophiles 2013;17:1-13.

21. Hozzein WN, Goodfellow M. Nocardiopsis arabia sp. nov. a halotolerant actinomycete isolated from a sand-dune soil. Int J Syst Evol Microbiol 2008;58:2520-4

22. Hozzein WN, Li WJ, Ali MI, Hammouda O, Mousa AS, Xu LH, et al. Nocardiopsis alkaliphila sp. nov. a novel alkaliphilic actinomycete isolated from desert soil in Egypt. Int $\mathrm{J}$ Syst Evol Microbiol 2004:54:247-52.

23. Bennur T, Kumar AR, Zinjarde S, Javdekar V. Nocardiopsis species: Incidence, ecological roles and adaptations. Microbiol Res
2015;174:33-47.

24. Saibabu V, Niyonzima FN, More SS. Isolation, partial purification and characterization of keratinase from Bacillus megaterium. Int Res J Biol Sci 2013;2(2):13-20.

25. Shirling EB, Gottlieb D. Methods for characterization of Streptomyces species. Int J Syst Bacteriol 1966;16(3):313-40.

26. Omran R. Corrosive lesions at concrete infrastructures as promising source for isolating bioactive actinobacteria. Am $J$ Life Sci 2015;3(4):247-56

27. Goodfellow M, Trujillo ME. Family II. Nocardiopsaceae. In: Parte A, Whitman W, Goodfellow M, Kämpfer P, Busse HJ, Trujillo ME, et al., editors. Bergey's Manual of Systematic Bacteriology. The Actinobacteria. $2^{\text {nd }}$ ed., Vol. 5. New York: Springer-Verlag; 2012. p. 1889-908

28. León J, Aponte JJ, Rojas R, Cuadra D, Ayala N, Tomás G, et al. Study of marine actinomycetes isolated from the central coast of Peru and their antibacterial activity against methicillin-resistant Staphylococcus aureus and vancomycin-resistant Enterococcus faecalis. Rev Peru Med Exp Salud Publica 2011;28:237-46.

29. Madigan MT, Martinko JM, Stahl DA, Clark DP. Commercial productsand biotechnology. In: Brock Biology of Microorganisms. $13^{\text {th }}$ ed. San Francisco: Benjamin Cumings; 2012. p. 415-6.

30. Baker GC, Smith JJ, Cowan DA. Review and re-analysis of domainspecific 16S primers. J Microbiol Methods 2003;55:541-55.

31. Wright ES, Yilmaz LS, Noguera DR. DECIPHER, a search-based approach to chimera identification for $16 \mathrm{~S}$ rRNA sequences. Appl Environ Microbiol 2012;78:717-25

32. Zhang Z, Schwartz S, Wagner L, Miller W. A greedy algorithm for aligning DNA sequences. J Comput Biol 2000;7(1-2):203-14.

33. Tamura K, Nei M, Kumar S. Prospects for inferring very large phylogenies by using the neighbor-joining method. Proc Natl Acad Sci U S A 2004;101:11030-5.

34. Kumar S, Stecher G, Tamura K. MEGA7: Molecular evolutionary genetics analysis Version 7.0 for bigger datasets. Mol Biol Evol 2016;33(7):1870-4.

35. Saitou N, Nei M. The neighbor-joining method: A new method for reconstructing phylogenetic trees. Mol Biol Evol 1987;4:406-25.

36. Wawrzkiewicz K, Lobarzewski J, Wolski T. Intracellular keratinase of Trichophyton gallinae. J Med Vet Mycol 1987;25:261-8.

37. Bradford MM. A rapid and sensitive method for the quantitation of microgram quantities of protein utilizing the principle of protein-dye binding. Anal Biochem 1976;72:248-54.

38. Naumova IB, Kuznetsov VD, Kudrina KS, Bezzubenkova AP. The occurrence of teichoic acids in streptomycetes. Arch Microbiol $1980 ; 126: 71-5$

39. Omran R, Kadhem MF. Isolation and identification of antibioticproducing actinomycetes. J Babylon Univ 2012;22(1):285-92.

40. Singh S, Shrivastava AR, Gupta A, Singh AK, Gopalan N, Chaudhary HS. Keratinloytic actinomycetes isolated from poultry waste. J Chem Pharm Res 2012;4(9):4107-11.

41. Saha S, Dhanasekaran D, Shanmugapriya S, Latha S. Nocardiopsis sp. SD5: A potent feather degrading rare actinobacterium isolated from feather waste in Tamil Nadu. India J Basic Microbiol 2013;53:608-16.

42. Kadiri SK, Yarla NS. Optimization of antibacterial metabolites production by Streptomyces fradiae. Int $\mathrm{J}$ Pharm Pharm Sci 2015;7(1):223-5

43. Duddu MK, Guntuku G. Isolation, screening and characterization of antibiotic producing actinomycetes from kapuluppada plastic waste dumping yard, Visakhapatnam. Int J Pharm Pharm Sci 2016; 8(11): $221-9$

44. Omran R, Kadhem MF. Production, purification, and characterization of bioactive metabolites produced from rare actinobacteria Pseudonocardia alni. Asian J Pharm Clin Res 2016;9(3):1-9.

45. Sun H, Lapidus A, Nolan A, Lucas S, Del Rio TG, Tice H, et al. Complete genome sequence of Nocardiopsis dassonvillei type strain (IMRU 509T). Stand Genomic Sci 2010;3:325-36.

46. Matikevičienė V, Grigiškis S, Sirvydytė K, Levišauskas D, Dižavičienè $\mathrm{O}$, Masiliūnienè $\mathrm{D}$, et al. Optimization of keratinase production by Actinomyces fradiae 119 and its application in degradation of keratin containing wastes. Environment Technology Resources. Proceedings of the $8^{\text {th }}$ International Scientific and Practical Conference. Vol. 1. 2011. p. 294-300.

47. De Azeredo LA, De Lima MB, Coelho RR, Freire DM. Thermophilic protease production by Streptomyces sp. 594 in submerged and solid-state fermentations using feather meal. J Appl Microbiol 2006;100:641-7.

48. Fakhfakh-Zouari N, Haddar A, Hmidet N, Frikha F, Nasri M. Application 
of statistical experimental design for optimization of keratinases production by Bacillus pumilus A1 grown on chicken feather and some biochemical properties. Process Biochem 2010;45:617-26.

49. Bishop M, Bott SG, Barron AR. A new mechanism for cement hydration inhibition: Solid-state chemistry of calcium nitrilotris (methylene) triphosphonate. Chem Mater 2003;15:3074-88.

50. Ningthoujam DS, Kshetri P, Sanasam S, Nimaichand S. Screening, identification of best producers and optimization of extracellular proteases from moderately halophilic alkalithermotolerant indigenous actinomycetes. World Appl Sci J 2009;7:907-16.

51. Gohel SD, Singh SP. Purification strategies, characteristics and thermodynamic analysis of a highly thermostable alkaline protease from a salt-tolerant alkaliphilic actinomycete, Nocardiopsis alba OK-5. J Chromatogr B Analyt Technol Biomed Life Sci 2012;889-890:61-8.

52. Rohamare SB, Dixit V, Nareddy PK, Sivaramakrishna D, Swamy MJ, Gaikwad SM. Polyproline fold-In imparting kinetic stability to an alkaline serine endopeptidase. Biochim Biophys Acta 2013;1834(3):708-16

53. Mitsuiki S, Sakai M, Moriyama Y, Goto M, Furukawa K. Purification and some properties of a keratinolytic enzyme from an alkaliphilic Nocardiopsis sp. TOA-1. Biosci Biotechnol Biochem 2002;66(1):164-7. 